JFFI. 2019; 6(2) 360-362

www.jurnal.farmasi.umi.ac.id/index.php/fitofarmakaindonesia

\title{
UJI TOKSISITAS EKSTRAK ETANOL TERPURIFIKASI BIJI MAHONI (Swietenia mahagoni)
}

\author{
Virsa Handayani, Ahmad Najib, Rezki Amriati Syarif, Abdullah Mahmud, \\ La Hamidu, Aktsar Roskiana Ahmad* \\ Universitas Muslim Indonesia \\ *aktsar.roskiana@umi.ac.id
}

Submission Date: 23-03-2019; $\quad$ Review Completed: 20-05-2019; $\quad$ Accepted Date: 08-06-2019

\begin{abstract}
Mahoni is a medical plant which have the potential as drug. The aims of this research were to analysis phytochemical content and to test the toxicity of ethanol extract of seed from Mahoni. The Phytochemicals that analyzed were total phenolic, total flavonoid and condensed tannin. Toxicity test was assessed using BSLT method. Extraction was done by maseration method using ethanol as the solvent. In BSLT method, the shrimp larvae were placed in a series of test solution of varied concentration. The value of $L C_{50}$ were obtained based on calculation of shrimp larvae lethality percentage using probit analysis. $L C_{50}$ values of ethanol extract were 0,95 ppm.
\end{abstract}

Keywords: mahoni; toksisistas; Swietenia mahagoni (L.) Jacq

\section{PENDAHULUAN}

Indonesia merupakan salah satu negara yang memiliki banyak keanekaragaman hayati dan mendapatkan peringkat keanekaragaman hayati tertinggi kedua didunia sebagai wilayah hutan tropika setelah Brasil. Dari 40.000 jenis flora yang ada didunia, terdapat 30.000 jenis flora di jumpai di Indonesia dan 940 jenis diantaranya berkhasiat sebagai tanaman obat tradisional (Pertamawati, Nuralih \& Fahrudin 2014, vol. 7, h. 89). Masyarakat Indonesia telah lama mengenal dan menggunakan tanaman obat sebagai salah satu upaya penanggulangan suatu penyakit. Pengetahuan tentang tanaman yang berkhasiat sebagai obat diperoleh dari pengalaman dan keterampilan nenek moyang yang telah diwariskan secara turuntemurun dari generasi ke generasi berikutnya (Tekha, Akkas \& Kartika 2015, vol. 13, h. 19). Salah satu tanaman yang berkhasiat sebagai obat adalah biji mahoni. Hasil penelitian terhadap biji mahoni (Swietenia mahagoni (L.) Jacq.) menunjukkan bahwa biji mahoni memiliki beberapa aktivitas antara lain sebagai antioksidan, antihelmentik, dan antimikroba (Kaur, et al. 2016a, h. 367; Kaur, et al. 2016b, h. 1068). Adapun senyawa yang terkandung dalam biji mahoni antara lain glikosida, flavonoid, saponin, dan tanin (Kaur, et al. 2016, vol. 8, h. 1066), dimana senyawa tanin dan flavonoid merupakan golongan senyawa fenolik yang memilki khasiat sebagai antiproliferasi dan apoptosis terhadap sel kanker (Meiyanto 2008, vol. 19, h. 17).
Metode BSLT merupakan salah satu metode awal yang digunakan untuk mengamati toksisitas suatu senyawa dan merupakan metode penapisan untuk aktivitas antikanker senyawa kimia dalam ekstrak tanaman. Metode BSLT ditujukan terhadap tingkat kematian larva udang Artemian salina Leach yang disebabkan oleh ekstrak uji. Hasil yang didapatkan dihitung sebagai nilai LC50, dimana senyawa dengan LC50<30 ppm dapat berpotensi sebagai suatu senyawa aktif yang memberikan efek antikanker (Inayah, Ningsih, \& Adi 2013, vol. 2, h. 94).

\section{METODE PENELITIAN \\ A. Alat dan Bahan}

Alat yang digunakan dalam penelitian ini adalah aerator, botol semprot, cawan porselin, corong, erlenmeyer, gelas kimia, gelas ukur, mikropipet, seperangkat alat maserasi, seperangkat alat penetasan telur, seperangkat alat rotavapor, statif, timbangan analitik, pipet tetes, dan vial.

Bahan yang digunakan dalam penelitian ini adalah air laut, alumunium foil, biji mahoni (Swietenia mahagoni (L.) Jacq.), dimetil sulfoksida (DMSO) 1\%, kertas saring, larva udang Artemia salina Leach, metanol (96\%), dan suspense ragi.

\section{B. Pengujian Brine Shrimp Lethality Test}

Penyiapan Larva

Disiapkan air laut, kemudian disaring dengan kertas whatman. Bejana penetas diberi sekat sehingga memiliki dua sisi ruang, yaitu sisi terbuka 
dan sisi tertutup (gelap). Telur Artemia Salina Leach di masukkan ke dalam bejana yang sudah berisikan air laut kemudian di sinari dengan lampu pijar 15 watt. Pada bejana diisi dengan $\pm 50-100 \mathrm{mg}$ telur udang untuk penetasan. Setelah 24 jam, telur yang telah menetas menjadi nauplii di pidahkan ke tempat lain, dan 24 jam kemudian nauplii tersebut dapat di gunakan sebagai hewan uji (Djamil \& Anelia 2009, vol. 7, h. 68; Ningdyah, Alimuddin \& Jayuska 2015, vol. 4, (1) h. 77).

Pembuatan Larutan Uji

Ekstrak metanol dan air biji mahoni (Swietenia mahagoni (L.) Jacq.) dibuat pada konsentrasi $10 \mathrm{ppm}, 50 \mathrm{ppm}, 100 \mathrm{ppm}, 250 \mathrm{ppm}, 500$ ppm, dan 1000 ppm. Larutan stok dibuat dengan menimbang $100 \mathrm{mg}$ ekstrak yang dilarutkan dalam 2 $\mathrm{mL}$ aquades. Jika sampel tidak larut/ sukar larut, ditambahkan dimetil sulfoksida (DMSO) $1 \%$ sebanyak 0,1-50 $\mu \mathrm{g}$ atau 2 tetes saja dan ditambahkan aquades hingga volumenya mencapai $100 \mathrm{~mL}$ sehingga didapatkan konsentrasi larutan stok 1000 ppm (Djamil \& Anelia 2009, vol. 7 h. 68; Ningdyah, Alimuddin \& Jayuska 2015, vol. 4, no.1, h. 77). Larutan stok, selanjutnya diencerkan pada konsentrasi $10 \mathrm{ppm}, 50 \mathrm{ppm}, 100 \mathrm{ppm}, 250 \mathrm{ppm}$.
Pengujian Larva

Uji toksisitas dilakukan pada masing masing ekstrak sampel. Setiap konsentrasi ekstrak sampel dibuat dalam 3 kali repitasi. Selanjutnya pada tiap konsentrasi larutan dimasukkan 10 ekor larva Artemia salina ke dalam vial. Untuk kontrol positif dimasukkan $5 \mathrm{~mL}$ air laut tanpa larutan uji. Pengamatan dilakukan selama 24 jam terhadap kematian larva Artemia salina kemudian dihitung jumlah larva yang mati dari tiap vial lalu dilanjutkan dengan analisa probit untuk menentukan $\mathrm{LC}_{50}$.

\section{HASIL DAN PEMBAHASAN Pengujian toksisitas}

Pengujian toksisitas larva dilakukan dengan metode BLST (Brine Shrimp Lethality Test). Ekstrak kulit batang kersen diuji ketoksikannya dalam mematikan larva dengan perlakuan perbedaan konsentrasi ekstrak. Konsentrasi yang dibuat yaitu: 1;10;100 dan $1000 \mathrm{ppm}$, rentang konsentrasi ini dipilih karena sampel dikatakan toksik apabila nilai $\mathrm{LC}_{50}$ kurang dari $1000 \mathrm{ppm}$. Hasil uji toksisitas ekstrak etanol biji mahoni dapat dilihat pada Tabel 1.

Tabel 1. Hasil uji toksisitas biji mahoni (Swietenia mahagoni (L.) Jacq.)

\begin{tabular}{ccccccc}
\hline \multirow{2}{*}{ Sampel uji } & \multirow{2}{*}{ Replikasi } & \multicolumn{5}{c}{ Jumlah larva udang yang mati tiap konsentrasi } \\
\cline { 3 - 7 } & 1 & $\mathbf{1}$ & $\mathbf{1 0}$ & $\mathbf{1 0 0}$ & $\mathbf{1 0 0 0}$ & $\mathbf{1 0 0 0 0}$ \\
\hline Ekstrak Etanol Biji mahoni & 2 & 7 & 8 & 9 & 9 & 10 \\
(Switenia mahagoni) & 3 & 6 & 7 & 8 & 9 & 10 \\
& & 20 & 23 & 25 & 27 & 30 \\
Total kematian & & $66,66 \%$ & $76,66 \%$ & $83,33 \%$ & $90 \%$ & $100 \%$ \\
\% kematian & & &
\end{tabular}

Tabel 1 menunjukkan bahwa semakin tinggi konsentrasi ekstrak maka kematian larva akan semakin tinggi, sehingga kematian larva dipengaruhi oleh peningkatan konsentrasi dalam sampel. Hasil pengujian yang diolah menggunakan analisis probit, menunjukkan nilai LC50 dari biji mahoni yaitu: 0.95 ppm. Hal ini menunjukkan ekstrak etanol biji mahonisangat toksik. Nilai LC50 yang kecil dari suatu sampel menunjukkan tingginya kandungan senyawa bioaktifnya. Tingginya kandungan senyawa bioaktif dari ekstrak etanol biji mahoni terhadap larva udang A. salina disebabkan karena adanya senyawa fenolik yang cukup tinggi (Harborne, 1996). Adanya senyawa flavonoid dalam sel dapat menyebabkan pecahnya membran sel. Hal ini dikarenakan gugus $\mathrm{OH}-$ pada flavonoid berikatan dengan protein integral membran sehingga transpor aktif $\mathrm{Na}+$ dan $\mathrm{K}+$ terhenti. Transpor aktif yang terhenti menyebabkan pemasukan ion $\mathrm{Na}+$ dan $\mathrm{K}+$ tidak terkendali dalam sel, yang menyebabkan pecahnya membran sel.
Membran sel yang pecah menyebabkan kematian pada sel (Scheuer, 1994).

\section{KESIMPULAN}

Uji toksisitas ekstrak etanol biji mahoni dengan menggunakan metode Brine Shrimp Lethality Test menunjukkan bahwa ekstrak etanol biji mahoni bersifat sangat toksik dengan nilai $\mathrm{LC}_{50} 0,95 \mathrm{ppm}$.

\section{DAFTAR PUSTAKA}

Chasani M, Fitriaji RB, Purwati. 2013. Fraksionasi ekstrak metanol kulit batang ketapang (Terminalia catappa Linn.) dan uji toksisitasnya dengan metode BLST (Brine Shrimp Lethality Test). Jurnal Molekul

Dewanjee, S.; Maiti, A.; Das, A.K.; Mandal, S.C.; Dey, S.P. Swietenine: A potential oral hypoglycemic from Swietenia macrophylla seed. Fitoterapia 2009, 80.

Djamil, R \& Anelia, T 2009, 'Penapisan Fitokimia, Uji BSLT, dan Uji Antioksidan Ekstrak 
Metanol Beberapa Spesies Papilonaceae', Jurnal Ilmu Kefarmasian Indonesia, vol. 7, no. 2, pp. 65-71.

Kaur, H, Amini, MH, Prabhakar, PK, Singh, A \& Suttee, A 2016, 'Phytochemical Screening and Antimicrobial Activity of Caesalpinia sappan L. Leaves', International Journal of Pharmacognosy and Phytochemical Research, vol. 8, no. 6, pp. 1064-1069.

Mun'im A., Hanani E., 2011. Fitoterapi Dasar. Edisi Pertama. Jakarta: PT. Dian Rakyat.

Meiyanto, E, Susidarti, RA, Handayani, S \& Rahmi, F 2008, 'Ekstrak Etanolik Biji Buah Pinang (Areca catechu L.) mampu menghambat proliferasi dan memacu apoptosis sel MCF7', Majalah Farmasi Indonesia, vol. 19, no. 1, pp.12-19.

Pertamawati, Nuralih \& Fahrudin, F 2014, 'Ekstrak Secang sebagai Bahan Diuretikum (Percobaan terhadap Tikus Putih Jantan Galur Spraque Dawley)', Al-kauniyah Jurnal Biologi, vol. 7, no. 2, pp. 89-93.

Tekha, KN, Akkas, E, \& Kartika, R 2015, 'Uji Toksisitas Ekstrak Kelopak Jantung Pisang Kepok (Musa Paradisiaca Linn.) dengan Metode BSLT (Brine Shrimp Lethality Test), Jurnal Kimia Mulawarman, vol. 13, no. 1, pp. 19-22. 